\title{
Uma beleza congelante: a morte e sexualidade em A Rainha da Neve, de Hans Christian Andersen e suas refigurações
}

\author{
A freezing beauty: death and sexuality in The \\ Snow Queen by Hans Christian Andersen and its \\ refigurations
}

\section{$\underline{\underline{\text { Lígia R M C Menna }}}$}

1 Doutora em Letras na área de Estudos Comparados de Literaturas em Língua Portuguesa (FFLCH-USP). Professora titular da UNIP- Universidade Paulista, membro dos Grupos de Pesquisa/ CNPQ: Produções Literárias e Culturais para Crianças e Jovens (FFLCH-USP) e Encontros Interculturais na EAD: Narrativas de vida dos diferentes brasis (UNIP INTERATIVA). Pós-doutorado em curso, sob a supervisão da Prof. ${ }^{a} \operatorname{Dr}^{\mathrm{a}}$ Maria Zilda da Cunha, com o projeto: "Releituras do maravilhoso: A Rainha da Neve, de Hans Christian Andersen, suas figurações e múltiplos diálogos”. Contato: mennaligia@gmail.com 
RESUMO: A bela e congelante Rainha da Neve, do conto homônimo de Hans Christian Andersen (Snedronningen, The Snow Queen, 1844), adquire sobrevidas em outras narrativas, tanto literárias como audiovisuais, permanecendo ainda viva no imaginário contemporâneo. Esse conto andersiano, de tessitura complexa, construído no contexto do romantismo, entre o espiritualismo cristão e o maravilhoso pagão, constitui-se em uma narrativa de formação, um rito de passagem da infância para a vida adulta, do qual depreendemos tanto o prenúncio para a morte, como os primeiros contatos com sexualidade.

Este artigo propõe-se a analisar as simbologias depreendidas dessa misteriosa personagem refletidas, ou não, em suas refigurações Jadis, a feiticeira branca de As Crônicas de Nárnia, de C. S. Lewis e Elsa, da animação Frozen: uma aventura congelante (Disney, 2013) com destaque para o protagonismo feminino.

PALAVRAS-CHAVE: A Rainha da Neve; Sexualidade; Morte; Refiguração; Imaginário.

ABSTRACT: The beautiful and freezing Snow Queen, from Hans Christian Andersen's eponymous tale (Snedronningen, The Snow Queen, 1844), survives on other narratives, both literary and audiovisual, still alive in contemporary imagery. This Andersen's tale of complex fabrication, built in the context of romanticism, between christian spiritualism and the marvelous pagan, constitutes a narrative of formation, a rite of passage from childhood to adulthood, from which we foresee both the foreshadowing death, as the first contacts with sexuality. This article intends to analyze the inferred symbologies of this mysterious personage reflected, or not, in hers refiguration, as Jadis, the white witch of C. S. Lewis' The Chronicles of Narnia; and Elsa, from Frozen (Disney, 2013), highlighting female protagonism.

KEYWORDS: The Snow Queen, Sexuality; Death; Refiguration; Imaginary. 


\section{Introdução}

O conto “A Rainha da Neve” (Snedronningen, The Snow Queen), de Hans Christian Andersen, publicado em 21 de dezembro de 1844 no primeiro volume dos Novos Contos de Fadas, apresenta uma intrincada composição, em que se mesclam o maravilhoso pagão ao espiritualismo cristão, com marcas do Romantismo em meio ao realismo cotidiano.

Vale destacar que a simbologia depreendida da misteriosa e bela rainha de cabelos platinados e poderes congelantes antecede à produção andersiana, já que se sustenta sobre a mitologia grega e nórdica, em divindades como Perséfone, Skadi, Freya e Hela, remetendo à sexualidade, ao feminino e à própria representação da morte.

Considerando essa complexa tessitura e vários aspectos da trama - como o fato de Kay ser seduzido e enfeitiçado pela Rainha e seus gélidos beijos, de Gerda partir em busca do amigo para resgatá-lo com suas mornas lágrimas, e do amadurecimento das personagens levam-nos a considerar essa narrativa uma analogia aos primeiros contatos com a sexualidade em um rito de passagem da infância para a vida adulta, percurso pelo qual a morte, revestida pela beleza, também é vislumbrada.

Ao longo de nossas pesquisas, confirmamos que há um variado leque de releituras e adaptações desse conto, tanto literárias quanto cinematográficas ou televisivas; assim como múltiplas, e por vezes contrastantes, refigurações da sua personagem homônima, uma rainha de poder congelante, conhecida por seu mistério, magia, beleza e sedução.

$\mathrm{Na}$ literatura, uma das refigurações mais evidentes é Jadis, A Feiticeira Branca, autointitulada "A rainha de Nárnia", presente nos dois primeiros livros de As Crônicas de Nárnia, de C. S. Lewis: O sobrinho do mago e O Leão, a Feiticeira e o Guarda-Roupa.

Nas narrativas fílmicas, uma das figuras mais lembradas é a princesa/rainha Elsa, de Frozen: uma aventura congelante (Frozen, Disney, EUA, 2013). Contudo, a bela rainha platinada ainda pode ser encontrada em A Rainha da Neve (Snezhnaya koroleva, The Snow Queen, URSS, 1957); O Reino Gelado (Snezhnaya koroleva, The Snow Queen, Wizart animation, Rússia, 2012); e na série Era uma vez (Once Upon A time, ABC, Disney, 4ª temporada, 2014), entre muitas outras produções.

Como podemos observar, a personagem Rainha da Neve tem permanecido viva no 
imaginário de muitos escritores, desenhistas, roteiristas, diretores, e seus públicos, em diferentes contextos de produção. Tomemos como base, dentre as várias acepções do termo imaginário, o que Wunenburger propõe:

[...]imaginário (é) um conjunto de produções, mentais ou materializadas em obras, com base em imagens visuais (quadro, desenho, fotografia) e linguísticas (metáfora, símbolo, relato), formando conjuntos coerentes e dinâmicos, referentes a uma função simbólica no sentido de um ajuste de sentidos próprios e figurados (WUNENBURGER,2007, p. 11).

Vale considerar que a simbologia depreendida em um certo imaginário pode reverberar ou mesmo se modificar ao longo de releituras e recriações, por meio de suas personagens figuradas e refiguradas.

Quando nos referimos à figuração e refiguração da personagem, é preciso enfatizar que esses termos são polissêmicos, assim como o próprio termo "figura". Para nossas análises, vamos considerar que figura é, segundo Carlos Reis:

[...] toda entidade ficcional ou ficcionalizada que desempenha funções na composição e na comunicação instaurada pelo relato ou que vive acontecimentos nele narrados. A manifestação mais evidente da entidade designada como figura é a personagem[...] (REIS, 2018, p. 163).

Assim, mesmo havendo a possibilidade de o narrador ser uma figura, focamos nossas análises na personagem Rainha da Neve, figurada, ou mesmo refigurada por Andersen e refigurada em outros contextos:

A figuração designa um processo ou um conjunto de processos discursivos e metaficcionais que individualizam figuras antromórficas localizadas em universos diegéticos específicos, com cujos integrantes aquelas figuras interagem enquanto personagens. (REIS, 2018, p. 164).

Vale acrescentar que a figuração, segundo Reis, é um processo dinâmico, gradual e complexo; não se esgota em um lugar específico do texto, pois vai sendo construída ao longo 
da narrativa, além do que, não se restringe à descrição e não pode ser confundida simplesmente com a caracterização da personagem.

Da noção de figuração decorre o conceito de refiguração, o qual se reporta ao

[...] processo de reelaboração narrativa de uma figura ficcional (normalmente uma personagem), no mesmo ou em diferentes suportes e linguagens. Pressupõe-se, deste modo, que as figuras ficcionais não são entidades restringidas e estaticamente fixadas na figuração a que uma certa narrativa as submeteu (REIS, 2018, p. 161).

Como já dito, devido a essas refigurações, as personagens podem adquirir sobrevidas, como ocorre com a Rainha da Neve. Para essa percepção, é preciso identificá-la no conto andersiano, para, enfim, reconhecê-la em outras produções.

Vejamos a primeira vez que a personagem surge para o jovem Kay:

Esse floco foi ficando cada vez maior, até que se transformou numa mulher vestida com o mais fino algodão branco e parecia ser feita de milhões de flocos em forma de estrela. Ela era bela e graciosa, mas era de gelo, de gelo brilhante e cintilante (ANDERSEN, 2017, p. 108. Grifos nossos).

A partir de tal caracterização, por sua beleza, sua brancura e seu ar gélido, é possível a vislumbramos, por exemplo, como já dito, em Jadis, a Feiticeira Branca, de. As crônicas de Nárnia, de C. S. Lewis, como destacamos a seguir:

Estava também envolta em peles brancas até o pescoço, e trazia, na mão direita, uma longa varinha dourada, e uma coroa de outro na cabeça. Seu rosto era branco (não apenas claro), branco como a neve, como o papel, como o açúcar. A boca se destacava, vermelhíssima. Era, apesar de tudo, um belo rosto, mas orgulhoso, frio, duro[...] (LEWIS, 2009, p. 115).

Além disso, a personagem de C. S. Lewis adquire vida em sua caracterização fílmica com a marcante atuação da atriz Tilda Swinton no filme Crônicas de Nárnia: O Leão, a Feiticeira e o guarda-roupa (Disney, 2005).

Considerando, como já visto, que a refiguração não se faz somente pela caracteriza- 
ção da personagem, será que encontraríamos índices de sexualidade e morte nas releituras do conto andersiano e em algumas de suas adaptações? Para este artigo, optamos por analisar tal possibilidade somente em duas personagens, as mais conhecidas: Jadis, das Crônicas de Nárnia e Elsa, de Frozen, em contraponto com a Rainha da Neve andersiana.

\section{A morte revestida pela beleza}

O conto "A Rainha da Neve" é um dos mais longos de Andersen, que o dividiu em sete partes devidamente intituladas, as quais correspondem a uma sucessão de aventuras da protagonista Gerda em meio a uma diversidade de personagens e locais. A saber: "Primeira história: que trata do espelho e dos cacos", "Segunda história: um rapazinho e uma menina"; "Terceira história: O jardim da mulher que sabia fazer feitiços"; "Quarta história: Príncipe e Princesa"; "Quinta história: A pequena salteadora"; "Sexta história: A mulher da Lapônia e a mulher da Finlândia" e "Sétima história: O que aconteceu no palácio da Rainha da Neve e o que se passou depois. "

No início, o narrador faz um preâmbulo contando-nos a história de um duende mau, o próprio diabo, “ da espécie mais malvada”, que inventou um espelho mágico para depois quebrá-lo em mil fragmentos, sendo que alguns desses iriam atingir o jovem Kay em seus olhos e coração, somente na segunda história:

Um dia, o Diabo estava de muito bom humor porque tinha acabado de fazer um espelho com um poder muito peculiar: tudo de bom e belo que se refletia nele parecia reduzir-se a quase nada, enquanto tudo que não tinha valor e era feio tornava-se mais proeminente e feio do que nunca (ANDERSEN, 2017, p. 104).

A Rainha não é mencionada nesse capítulo e, ao longo da narrativa, não se explicita qual seria a relação dela com o espelho ou com o Duende. Ela aparece somente na segunda e sétima história, com poucas falas e pouca ação. Ela é figurada lenta e metaforicamente, inicial-

2 Os títulos dos capítulos costumam variar conforme a tradução. 
mente vislumbrada, nem mesmo nomeada. Tanto o menino Kay como os leitores conhecem a Rainha aos poucos.

Na segunda história, o narrador nos apresenta Gerda e seu vizinho Kay, sua amizade, sua vida cotidiana. Em seguida, ao observar a neve por uma janela, ouvem da avó que os flocos de neve se assemelhavam a abelhas brancas. $\mathrm{O}$ menino pergunta se essas abelhas também tinham uma rainha, ao que a avó responde que sim: "Em muitas noites de inverno, ela voa pelas ruas e espreita pelas janelas. Depois elas gelam de maneira estranha, como se estivessem cobertas de flores" (ANDERSEN, 2017, p. 107). Gerda se assusta e pergunta se a Rainha da Neve poderia entrar na casa, ao que o jovem Kay responde: "Bem, ela que entre - gritou o menino - Eu a colocava no fogão quente e a derretia" (ANDERSEN, 2017, p. 108).

Após essa cena, provavelmente como uma resposta a Kay, ou um prenúncio da morte, a Rainha aparece, mas ainda não é nomeada:

Ela era bela e graciosa, mas era de gelo, de gelo brilhante e cintilante. Mas mesmo sendo de gelo, estava viva, e os seus olhos brilhavam como estrelas, mas neles não se via serenidade e nem paz. Depois acenou com a cabeça e com a mão para a janela (ANDERSEN, 2017, p. 108.).

Somente no momento em que captura Kay é que seu nome será revelado: "O manto de pelo e o gorro eram feitos de neve, e era uma mulher, alta, elegante e ofuscadamente branca; ela era a Rainha da Neve em pessoa (ANDERSEN,2017, p.111)

O fato da Rainha de a Neve simbolizar a morte, ou seu prenúncio, pode ser confirmado em diferentes instâncias. Tomemos inicialmente como referência o que diz Sigmund Freud em seu texto "O tema dos três escrínios (ou a escolha do cofre)", de 1913, no qual reflete sobre o tema da escolha de um homem entre três mulheres, nesse caso, os cofres ou escrínios simbolizariam essas mulheres, sendo uma delas a própria morte.

Para desenvolver sua linha argumentativa, o autor cita inicialmente a peça $O$ Mercador de Veneza, de Willian Shakespeare, na qual os pretendentes de Porcia precisam escolher apenas um cofre (escrínio) entre três, a saber, um de bronze, um de prata e outro de ouro, diferentes opções para uma mesma mulher, mas apenas uma prevalecerá.

Adiante, Freud ainda cita Rei Lear e suas três filhas, relacionando-as com figuras mi- 
tológicas, como as Parcas/Moiras/Horas e a Morte. Tomando a literatura e a mitologia para sustentar sua argumentação, ao final de artigo, o pai da psicanálise conclui que um homem tem/terá três relações inevitáveis com uma mulher: a mulher que lhe dá à luz, sua mãe; a mulher que é a sua companheira, sua amada e a mulher que o destrói, a Terra-mãe, a morte, para onde retorna. Contudo, para Freud, o homem, que faz uso de sua atividade imaginativa para satisfazer os desejos que a realidade não satisfaz, rebela-se contra a morte, construindo narrativas míticas ou literárias em que a "Deusa da morte" é substituída pela "Deusa do Amor", humanizada por sua beleza.

Observemos, assim como apontado por Freud, que a morte é revestida pela beleza, materializada primeiramente em uma jovem "bonita e delicada, mas de gelo" e, posteriormente em uma mulher alta, elegante, bonita, com o "mais charmoso, o mais formoso rosto".

Ratificando, segundo Freud,

O homem, como sabemos, faz uso de sua atividade imaginativa a fim de satisfazer os desejos que a realidade não satisfaz. Assim sua imaginação rebelou-se contra o reconhecimento da verdade corporificada no mito das Moiras e construiu em seu lugar o mito dele derivado, no qual a Deusa da Morte foi substituída pela Deusa do Amor e pelo que lhe era equivalente em forma humana (FREUD,1996, p. 183).

Retomando o conto, sabemos que a Rainha da Neve aprisiona Kay em uma ambiência gélida e artificial, onde sempre é inverno: ele se torna uma pessoa fria pelo espelho, é enfeitiçado pelo beijo frio da rainha e permanece preso no frio castelo, como um morto-vivo.

Contudo, em sua ambivalência destruidora e criadora, a Rainha é responsável por gelar as montanhas e produzir a aurora boreal com seus clarões azuis. Como uma deusa, administra a neve e as gélidas paisagens, tão necessárias para a harmonia terrestre.

Nesse sentido, referenciamos novamente Freud, que constata que dentro da mitologia há deusas ambíguas, que celebram tanto a vida quanto a morte:

Mesmo a Afrodite grega não abandonara inteiramente sua vinculação com o mundo dos mortos, embora há muito tempo houvesse entregado seu papel ctônico a outras figuras divinas, a Perséfone ou à triforme Artêmis-Hécate. As grandes deusas-Mães dos povos orientais, contudo, parecem todas ter sido tanto criadoras quanto des- 
truidoras - tantas deusas da vida e da fertilidade quanto deusas da morte. Assim, a substituição por um oposto desejado em nosso tema retorna a uma identidade primeva (FREUD,1996, p. 183).

Dessa forma, a Rainha da Neve, que viaja para outras terras levando o frio para os vulcões e garantindo a fertilidade do solo, assemelha-se a essas deusas criadoras e destruidoras.

As relações estabelecidas entre o inverno e a morte tornam-se mais evidentes se recorrermos à mitologia nórdica, para a qual os mortos habitam uma terra congelada, denominada de "Niflheim", a qual existia antes do universo conhecido ser criado. Em seu centro, havia uma fonte gelada, "Hvergelmir", mãe de vários rios. Tornou-se o reino de Hel (Hela), deusa dos mortos: "Helheim". (BULFINCH,2013,587). Note-se que em língua inglesa "Hell" designa o inferno. Assim, a ideia de que o inferno seria um lugar quente advém de uma concepção cristã posterior. Ou seja, o surgimento da Rainha da Neve e seu poder invernal como símbolos da chegada da morte tornam-se mais evidentes.

Reforçando essa ideia, ainda podemos relacionar a figura da Rainha da Neve à deusa nórdica Skadi, uma gigante que se tornou deusa ao casar-se com Njord, um Vanir (deus da fertilidade). Segundo verbete da Nova Enciclopédia Mundial:

Skadi é mais conhecida em conjunto com seu marido (Njord) e seus enteados (Freyr e Freyja). Ela é uma personagem feminina ousada e corajosa nos épicos nórdicos, que desafiou a sociedade dominada pelos homens, exigindo que os Aesir (um clã de deuses) a compensassem pela morte de seu pai. $^{3}$

Quanto à etimologia do nome "Skadi”, encontramos, no mesmo verbete, a seguinte explicação:

O nome de Skadi significa "dano" ou "sombra", que reflete uma possível crença em seu status de gigante de gelo e portadora de frio, inverno e morte. Alguns mitólogos acreditam que, nos primeiros dias da mitologia nórdica, Skaði era venerada como

3 Disponível em http://www.newworldencyclopedia.org/entry/Skadi Acesso em 4 de abril de 2019. Tradução nossa. 
uma deusa da caça e rivalizava com as deusas Frigg e Freyja em termos de importância e popularidade. ${ }^{4}$

Se recorrermos à mitologia grega, conforme já apontado por Freud, citamos o mito de Perséfone, para o qual há diferentes versões. Vejamos a mais recorrente ${ }^{5}$.

Perséfone era filha de Deméter, deusa da agricultura e da terra cultivada, com o poderoso Zeus. Ela era uma bela jovem, virgem e despreocupada, conhecida também pelo nome "Core", a donzela. Certo dia Hades se apaixonou pela jovem e, com a conivência de Zeus, raptou-a e a levou para o mundo subterrâneo, o mundo dos mortos. Desesperada, a mãe a procurou por todo o mundo com um archote aceso em suas mãos. Ao descobrir seu paradeiro, Deméter ficou furiosa e recusou-se a voltar para o Olimpo sem a filha. Enquanto isso, a ordem natural foi perturbada, pois a terra tornou-se estéril e nada do que era plantado crescia. Zeus resolveu interceder para que Perséfone voltasse com sua mãe para o Olimpo; contudo, a jovem já comera uma romã, o que indicava sua permanência no mundo subterrâneo.

Após uma negociação dos deuses, decidiu-se que Perséfone seria a esposa de Hades, ou seja, a rainha dos mortos e que, a cada primavera, se reuniria com Demeter no Olimpo para que a terra fosse cultivada.

Esse mito é visto como uma alegoria para a fertilidade: Perséfone seria o grão semeado embaixo da terra para despontar em novos frutos durante a primavera.

Como podemos verificar, Perséfone representa dois arquétipos femininos, o da jovem virgem e o da rainha do mundo dos mortos, do submundo, beleza e morte em harmonia em uma única deidade.

Interessante observar que, segundo apontado por Fraser (1982), houve uma disputa entre as deusas Perséfone e Afrodite pelo belo Adônis, o que remete, a nosso ver, ao embate entre Gerda e a Rainha da Neve pelo pequeno Kay:

Em sua infância (de Adônis), a deusa (Afrodite) o ocultou numa arca, que confiou a

4 Disponível em: <http://www.newworldencyclopedia.org/entry/Skadi> Acesso em 4 de abril de 2019. Tradução nossa.

5 Informações colhidas no site greciaantiga.org, dadas pelo estudioso Wilson A Ribeiro Júnior. 
Perséfone, rainha dos infernos. Mas, quando Perséfone abriu a arca e viu a beleza da criança, recusou-se a devolvê-la a Afrodite, embora a deusa do amor tivesse ido, ela própria, ao inferno para resgatar seu amado do poder do túmulo (FRASER, 1982 p. 308).

Podemos ainda considerar que essa relação da Rainha da Neve com a morte já fazia parte do imaginário de Andersen, conforme constatamos no excerto em que narra a noite da morte de seu pai, em seu livro The true story of my life:

\footnotetext{
Meu pai morreu no terceiro dia depois disso. Seu cadáver estava deitado na cama: eu dormi com minha mãe. Um grilo cantou a noite inteira. "Ele está morto", disse minha mãe, dirigindo-se a ele; "tu não precisas chamá-lo. A donzela de gelo o buscou”. Eu entendi o que ela quis dizer. Lembrei-me de que, no inverno anterior, quando nossas janelas estavam congeladas, meu pai apontou para elas e nos mostrou uma figura como a de uma moça de braços estendidos. "Ela veio me buscar", disse ele, em tom de brincadeira. E agora, quando ele jazia morto na cama, minha mãe lembrou-se disso, o que também ocupou meus pensamentos (ANDERSEN, 1847, p. 10. Tradução nossa).
}

Em 1861, Andersen retornaria ao tema de forma mais explícita, por meio do pequeno romance $A$ Donzela do Gelo, que narra a história e o destino de Rudy. Segundo Nelly Novaes Coelho, nesse texto reforça-se

[...] a peculiar visão andersiana da existência humana: a exuberância da vida, condenada inexoravelmente a ser aniquilada pela morte: a "Donzela do Gelo", a senhora poderosa das geleiras, a inevitável morte que aguarda os homens (ANDERSEN, 2011, p.567).

Kay também morrerá, mas não literalmente. Ao ser atingido pelos fragmentos do espelho, torna-se um menino ríspido e insensível, indispõe-se com Gerda e, quando brincava sozinho com seu trenó, acaba por ser levado pela rainha para seu gélido castelo onde permanecerá enfeitiçado, inerte. Sua salvação está em Gerda.

Quanto às refigurações, comecemos por Jadis, A Feiticeira Branca, das Crônicas de 
Nárnia, de C. S. Lewis. É importante citar que essa personagem surge no primeiro livro, $O$ sobrinho do Mago, e precede à criação de Nárnia, pois lá estava presente, como um obstáculo para a paz, um mal eminente que se revelaria em breve, comprometendo a existência de um bem maior, representado pelo leão Aslan.

Ela é uma feiticeira de um mundo sombrio e foi desperta por Digory, o sobrinho do Mago, no caso o tio André, e trazida para o mundo real e cotidiano. Perde seus poderes e se autoproclama Imperatriz e não perde a oportunidade de manifestar sua crueldade e arrogância. Mesmo assim, encanta o tio André: "Moça valente! Que pena o temperamento dela! Mas que mulher, que mulher danada" (LEWIS, 2009, p. 63).

No livro O leão, a feiticeira e o guarda-roupa, Jadis é chamada de a Feiticeira Branca, mas se autoproclama a "Rainha de Nárnia" e mantém seus "súditos" imersos em um feitiço congelante.

A redundância descritiva com ênfase na brancura do rosto, "Seu rosto era branco (não apenas claro), branco como a neve, como o papel, como o açúcar", colabora para a construção de uma personagem não-humana, insólita e enigmática. Apesar de tão branco, frio, orgulhoso, duro, "era um belo rosto".

Quando Edmundo chega ao castelo da feiticeira sem seus irmãos, a crueldade da feiticeira se revela:

\footnotetext{
- Aqui estou, Majestade - disse Edmundo, avançando, aflito.

- Como se atreve a vir sozinho -perguntou a feiticeira em tom de ameaça - Não dei ordem para que trouxesse seus irmãos?

- Perdão, Majestade. Fiz o que pude. Eles estão aqui perto (...). Um sorriso cruel desenhou-se lentamente no rosto da feiticeira (LEWIS,2009, p. 146).
}

Vale dizer que a rainha andersiana não é descrita como má; é gentil com Kay, apesar de mantê-lo no cativeiro. É uma representação da morte revestida de beleza e a ela não são atribuídas marcas negativas, ao contrário do que ocorre com a personagem de Lewis. Lúcia, após encontrar o sr. Tumnus, relata o que sabe sobre a Feiticeira Branca:

[...]_. Uma pessoa horrorosa. Diz que é a rainha de Nárnia, embora não tenha o direito de ser rainha. É odiada por todos os faunos e dríades (...). É capaz de transformar as 
pessoas em pedra e de fazer mil coisas horríveis. É por causa de um encantamento dela que é sempre inverno em Nárnia, sempre inverno, mas o Natal nunca chega. Ela anda num trenó puxado por duas renas, tem uma varinha na mão e uma coroa na cabeça (LEWIS, 2009, p. 119. Grifos nossos).

Jadis mantém o reino em um inverno constante, triste e sem Natal, e transforma seus inimigos em pedra como uma forma de demonstrar sua crueldade e se manter no poder, adquirindo autoridade pelo medo. Para a Rainha da Neve, o controle do inverno faz parte de sua natureza divina. Os vulcões precisam ser congelados, o ciclo do natural, de inverno a inverno, precisa ser mantido para o equilíbrio vital da Terra.

Outra refiguração da Rainha da neve pode ser vista em Frozen, a versão da Disney, cujo título original era The Snow Queen. Contudo, essa versão em muito se distancia do conto de Andersen, mantendo apenas reminiscências à rainha de cabelos platinados com poderes de transformar tudo em gelo, representando um perigo para seu reino e para sua irmã Anna.

Segundo jornalista norte americano Jim Hill (HILL,2013), os estúdios Disney demoram mais de 70 anos para concretizar o desejo de levar A Rainha da Neve para as telas. A história esteve em desenvolvimento na Disney Animation durante boa parte da sua trajetória, ou seja, 74 anos, mas nenhuma das versões idealizadas durante esse longo período saiu do papel, já que, segundo o jornalista, os roteiristas não sabiam como desenvolver a personalidade abstrata da Rainha da Neve. No conto, podemos considerar Gerda a típica heroína e a Rainha sua antagonista; contudo, não há um confronto final, como dissemos, o que dificultou em muito a criação de um roteiro que agradasse ao público.

Em 1943, por exemplo, Walt Disney já discutia com Samuel Goldwyn a possibilidade de transformar o conto de Andersen em uma animação. Contudo, somente em 2011, quando Chris Buck foi escolhido para a direção, o projeto foi revitalizado, e decidiu-se, à época, que a Rainha da Neve seria irmã da heroína Anna, criando-se assim uma relação real para as duas personagens principais. Em 2012, Jennifer Lee assumiu o roteiro e a codireção e manteve-se a mesma base temática. Quanto à trama, destacamos que o conflito inicial se estabelece no fato de a bela e jovem Elsa, princesa e futura rainha, não ser capaz de controlar seus poderes congelantes, o que a leva a ser isolada do mundo e ser privada do convívio de sua irmã Anna. 
Em nenhum momento explica-se porque Elsa possui esses poderes, os quais são para ela uma verdadeira maldição, já que isso a leva a ser vista pelos pais como uma ameaça para sua pequena irmã, da qual é afastada e mantida assim, mesmo após a morte dos pais em um naufrágio. Adulta, é coroada rainha, mas, quando contrariada, torna-se uma ameaça para o próprio reino.

Em um contexto atual, em que a sororidade se evidencia e o empoderamento feminino tornou-se tema recorrente, quem salva Anna não é nenhum príncipe, o falso Hans, ou o apaixonado Kristoff, filho adotivo dos trolls, mas Elsa, com suas lágrimas e seu amor. O amor fraternal torna-se o ingrediente essencial para que Elsa controle seus poderes, finde o eterno inverno e governe seu reino em um ambiente harmônico e feliz.

Nessa releitura de A Rainha da Neve, nota-se que o protagonismo feminino permanece, sendo os personagens masculinos meros coadjuvantes. Contudo, as refigurações surgem além dos gêneros e não há uma correspondência simples entre as personagens.

Lembremos que Gerda sai em busca de seu amigo Kay para resgatá-lo, salvá-lo, enquanto o menino permanecia isolado no castelo congelante da Rainha da Neve. Em Frozen, Anna cumpre esse papel da heroína e parte em viagem para resgatar sua irmã, salvá-la dela mesma e do descontrole dos seus poderes, sendo Elsa uma referência tanto ao enfeitiçado Kay, quanto à Rainha que o aprisiona. Por outro lado, enquanto Kay permanecia enfeitiçado, com cacos do espelho do mal em seu coração e olhos, na animação, é Anna que é atingida no coração pelo raio de gelo, tornando-se uma estátua congelada e só retornando à vida com as lágrimas do amor de Elsa, as mesmas lágrimas de Gerda, aquelas que salvam, que fazem renascer. Personagens como Kristoff e Olaf resumem-se em todos os coadjuvantes, ou mediadores, que auxiliarão a jovem Anna a cumprir sua missão.

A beleza de Elsa e sua virgindade (como adulta ela permanece solteira, sem um par amoroso, como seria típico para uma princesa dos contos de fadas) são aspectos evidentes. Contudo, seria essa rainha Elsa também uma representação da morte revestida de beleza? $\mathrm{Na}$ animação, a rainha congelante torna-se humana, com a qual muitos poderiam se identificar, já que se sente deslocada, diferente das pessoas de sua família, como se não houvesse para ela um lugar nesse mundo. Quando seu poder é revelado, vê-se exposta, "nua" e se isola. Em sua ambivalência, assim como a Rainha da Neve, provoca o mal, pode levar à morte, mas também leva à vida. Elsa é humana, em toda sua complexidade e conflitos internos. 
Quanto aos matizes mitológicos, podemos considerar que também Elsa retoma o mito de Perséfone ao transitar por dois mundos, se assim considerarmos seus conflitos pessoais, e ser resgatada por sua irmã.

De forma interessante, a representação de Skadi divide-se em duplos. Como a deusa, Elsa e a Rainha da Neve dominam o frio e a morte, cabendo a Anna e Gerda sua coragem e ousadia.

\section{Feitiço, sedução e sexualidade}

Quando a Rainha da Neve coloca Kay em seu trenó, observamos ser a primeira vez que o autor lhe dá voz: Andamos muito rápido!" Disse ela. "Será possível que esteja tremendo de frio? Abrigue-se no meu casaco de pele de urso!" (ANDERSEN, 2017, p. 111).

A fala da personagem transmite zelo, um cuidado quase que maternal para com o menino que, na verdade, está sendo raptado. Contudo, a sensação do menino é como se estivesse afundando em um monte de neve.

Em seguida, ela pergunta se ele ainda sente frio e o beija na testa:

Brrr! Aquele beijo foi mais frio que o gelo. Sentiu-o até no coração, metade do qual já era um pedaço de gelo. Ele sentiu-se como se estivesse morrendo, mas apenas por um instante. Sentiu-se muito confortável e deixou de sentir frio (ANDERSEN, 2017, p. 112).

Interessante observar o uso do discurso indireto livre e a onisciência do narrador, que nos revela os pensamentos e sentimentos conflitantes do jovem Kay, criando empatia com os leitores, também propensos ao encantamento.

Em seguida, após beijá-lo duas vezes, a Rainha fez com que o menino se esquecesse de sua família e de Gerda, e revelou que não poderia mais beijá-lo, pois poderia matá-lo com seus beijos:

“Não vou beijá-lo mais”, disse ela, "porque se o fizer, você morre”. Kay olhou para ela. Era tão bela! Ele não conseguia imaginar um rosto mais inteligente e belo. Já 
não parecia feita de gelo como parecera antes, quando lhe acenou amistosamente à janela. Aos olhos dele, ela era perfeita, e Kay já não tinha medo nenhum (ANDERSEN, 2017, p. 112).

Observamos como, aos poucos, Kay não tem mais medo, tudo é natural, e a rainha se torna cada vez mais bela. Eis que o rapaz se encontra enfeitiçado, impossibilitado de qualquer ação. Esses trechos denotam, simbolicamente, o medo dos primeiros contatos sexuais e o prazer em conhecê-los, ou simplesmente vislumbrá-los. Mas Kay precisa ser resgatado por Gerda, já que está sendo iludido, envolto pelo feitiço do espelho e pelos beijos da Rainha. Vale ressaltar que a Rainha, mesmo não sendo humana, é um adulto, e Kay ainda é uma criança, o que torna a situação instigante. Como validar essa relação entre um menino e uma mulher adulta? E se essa mulher representasse a figura da própria mãe? Instigante e polêmica relação destinada a futuras reflexões.

A Rainha da Neve e Kay voltarão a aparecer somente na última e sétima história. Nesse longo espaço narrativo, o que se destaca são as aventuras e desventuras de Gerda à procura do amigo.

Ao final, tomamos conhecimento de onde estaria o rapaz. A Rainha da Neve o havia aprisionado como um morto-vivo em seu castelo, em uma ambiência gélida e artificial, imprimindo-lhe um desafio: "Se você conseguir formar essa palavra (Eternidade), será dono do seu próprio destino, e lhe dou o mundo inteiro e um novo par de patins" (ANDERSEN, 2017, p. 146). Curioso e insólito trecho, que compara um simples par de patins a um mundo inteiro. Aqui, parece-nos, Kay é tratado como a criança que realmente é. O desafio é imenso, já que Kay não raciocina, não sabe nem mesmo seu nome, perde sua identidade. Mesmo ao final, continuamos sem saber porque a rainha o raptou: somente por que ele a desafiou?

Seguindo o que foi proposto por Joseph Campbell quanto à jornada do herói, temos nesse ponto a "iniciação" de Kay, tão necessária para seu amadurecimento, após a "separação" ocorrida no segundo capítulo (CAMPBELL, 2004). Vale dizer que Gerda também passa por essa jornada, mas sua iniciação se realiza ao longo de suas diversas aventuras.

Em sua ambiguidade destruidora e criadora, a Rainha priva Kay de sua liberdade, mas também, como vimos, é responsável por gelar as montanhas e produzir a aurora boreal com 
seus clarões azuis. Como uma deusa, uma entidade da natureza, administra a neve e as gélidas paisagens, tão necessárias para a harmonia terrestre:

\footnotetext{
“Agora vou voar até os países quentes, quero ir ver os grandes caldeirões negros”. Ela se referia aos vulcões Etna e Vesúvio. “Tenho de embranquecê-los um pouco. Eles precisam, e ficarão tão bem com os limões amarelos e as uvas púrpuras (ANDERSEN, 2017, p. 146).
}

Essa é a última fala e aparição da Rainha da Neve. Quando Gerda chega ao castelo e salva Kay com suas mornas lágrimas e beijos, a Rainha já havia partido. Não há, portanto, um conflito final entre as protagonistas, como já dito. Como um duplo, em um espelho, a Rainha e Gerda de contrapõem, entre o invernal e o solar, entre o divino e o humano, entre o sonhado e o vivido, o imaginário e o real, respectivamente.

Observamos ainda que há constantes referências ao Menino Jesus, a anjos e à solar Gerda, cujas lágrimas e beijos mornos quebram o feitiço da Rainha. O imaginário cristão aqui se evidencia em contraponto à cultura nórdica e pagã. A ambiência para esses momentos é o do verão, quando há alegria, os campos estão abertos, as rosas florescem e as personagens encontram-se em harmonia, já adultos, mas ainda crianças em seu coração, como no desfecho, em um clássico final feliz, não tão comum a Andersen:

\footnotetext{
Kay e Gerda se olharam e por fim perceberam o significado do seu antigo salmo: “Onde as rosas florescem no vale tão docemente/ Lá encontrarás o Menino Jesus certamente”. E ali permaneceram sentados, crescidos, mas ainda crianças, crianças de coração. E era verão, quente e glorioso verão (ANDERSEN, 2017, p. 149).
}

Gerda, em sua jornada heroica, torna-se adulta. Kay é salvo por Gerda e também se torna adulto. Ambos, após a separação, partem para a iniciação e posterior retorno, seguindo a jornada do herói. Kay precisava passar por essa experiência com a Rainha, passar pelo inverno. Gerda transpões outros obstáculos em busca do rapaz, sua jornada é outra. Continuam amigos, agora crescidos, mas crianças em seu coração. Lembrando que eram amigos e vizinhos, nada há que os impeça de um romance amoroso, o que fica em aberto.

Em Frozen, não há qualquer referência à sexualidade, e sim à sororidade e, como 
dissemos, à importância do amor fraternal. Não há um rapaz enfeitiçado e os personagens masculinos ficam em segundo plano.

Em Crônicas de Nárnia, entretanto, consideramos que as referências à sedução e à sexualidade permanecem, mesmo que à revelia de C.S. Lewis.

Jennifer Miller, em seu artigo "No Sex in Narnia? How Hans Christian Andersen's "Snow Queen" Problematizes C.S. Lewis's The Chronicles of Narnia, afirma que a ausência de sexualidade e do amor romântico em As Crônicas de Nárnia foi uma opção consciente de Lewis que, em seu artigo “On Science Ficcion”(LEWIS, $1982^{6}$ apud MILLER, 2009), chegou a manifestar fobia e muito desconforto com histórias que insinuam ou relatam um caso amoroso (love affair) entre crianças. Inclusive, em carta a James Higgins, o autor afirma que "escrever para jovens certamente modificou meu jeito de escrever, o que exclui o amor erótico" (MILLER, 2009, $\mathrm{p}$ 115. Tradução nossa).

Contudo, a autora considera que, apesar dos esforços de Lewis em compor um mundo inocente, uma terra criada por e para crianças, sem espaço para sexualidade ou prazer (a não ser o prazer pelo divino), o fato de referenciar a rainha andersiana, ou mesmo seres mitológicos como o sátiro, na figuração do fauno Tumnus, estimula o imaginário dos leitores que conhecem essas referências, levando-os a vislumbrar índices de desejo sexual, sedução e sexualidade também na obra de Lewis. Para ela, o filme de 2005 só vem reforçar essa visão, principalmente pela escolha dos atores: a charmosa Tilda Swinton, como Jadis, já mencionada, e o jovem ator James MacVoy, como Tumnus.

Jadis não beija Edmundo, ela lhe dá uma bebida quente e o enfeitiça com o manjar turco, o seduz pelo estômago e incita-lhe a gula e a traição. Seus objetivos são bem claros, ela quer destruir os filhos de Adão e Eva, que, segundo uma profecia, seriam os futuros reis de Nárnia. Finge-se de gentil para alcançar seus sórdidos desejos de poder.

Como a serpente bíblica, provoca o menino pelo desejo. Ele não comerá uma maçã, mas um manjar turco (goma árabe), que lhe provoca uma fome insaciável. Simbolicamente, temos mais uma vez a atração de um menino por uma mulher mais velha, que o seduz pelo

6 LEWIS, C. S “On Science Fiction.” On Stories, and Other Essays on Literature. San Diego: Harvest Books, 1982. 55-68. 
estômago, como uma analogia materna, a mãe que alimenta. Não temos aqui a maçã, símbolo de fertilidade, de amor ou mesmo de conhecimento espiritual, na tradição celta, mas um doce viciante.

Como vemos, mulheres adultas enfeitiçam meninos, com objetivos distintos. Uma seduz por seus beijos, outra pelo estômago. Sua feminilidade, e eventual maternidade, são elucidadas. Contudo, Jadis representa o próprio Mal, uma ameaça a Aslan e à harmonia de Nárnia, sendo finalmente destruída. Já Rainha da Neve simplesmente desaparece, ruma para outros lugares onde o inverno se faz necessário, dando continuidade ao ciclo da vida.

Segundo Miller (2009), o desejo de Kay pela Rainha da Neve confunde-se ora com o desejo por uma mulher mais velha, ora com o desejo pela figura materna, conforme apontamos anteriormente, algo edipiano, por assim dizer. Para tal afirmação, a autora referencia Jorgen Johansen: "a prisão de Kay no castelo da Rainha da Neve ocorre quando ele, ainda menino, está prestes a se tornar um jovem adulto e adora uma mulher altamente ambígua que ele vê como metade mãe e metade amada" (JOHANSEN, $2002^{7}$ apud MILLER, 2009, p. 122. Tradução nossa). Tais desejos desafiam o ideal tradicional do amor romântico, o qual só poderia ser concretizado na relação entre Kay e Gerda.

Lewis, por outro lado, procura eliminar qualquer possibilidade de amor romântico quando nos apresenta Edmund e Lúcia, personagem semelhante a Gerda em suas ações heroicas, como irmãos.

\section{Considerações finais}

Pudemos constatar que a Rainha andersiana, mesmo quando vista como um prenúncio da morte, não representa "o mal”, mas sim uma etapa do ciclo vital, necessária para o amadurecimento e a harmonia do universo. Ela é um ser etéreo que controla a natureza, inspirada em deusas mitológicas, como Perséfone e Skadi, ou mesmo Hela, a deusa dos mortos na

7 Johansen, Jorgen Dines. “Counteracting the Fall: 'Sneedronningen' and 'Iisjomfruen': The Problem of Adult Sexuality in Fairytale and Story.” Scandinavian Studies 74.2 (Summer 2002): 140. 
terra gelada de Niflheim. Ela é a deusa que pode representar a mulher mais velha, a amada, a própria mãe. Sua figura nos remente não somente à morte e seu prenúncio, mas à fertilidade e à sexualidade.

Além disso, como apresentado por Andersen em suas memórias, a personagem Rainha da Neve já fazia parte do imaginário do autor como uma referência à chegada da morte ou da própria morte. E, como apontado por Sigmund Freud, a morte revestida pela beleza é uma forma de inconformismo ou até rebeldia pelo que inevitavelmente está por vir, o retorno do homem à Terra-mãe.

$\mathrm{Na}$ animação Frozen, resta a figura da bela princesa com poderes congelantes, os quais precisava aceitar e controlar. Elsa, seguindo seu percurso de heroína, também amadurece, torna-se rainha e mulher, redimida por seu amor fraternal, passa a controlar seus poderes e demonstra que é possível ser feliz sem um príncipe encantado.

Já Jadis, a Feiticeira Branca, composta a partir do ideário cristão, representa o próprio Mal, liberto pela curiosidade dos homens. Como a serpente no episódio de Adão e Eva, representa o demônio sedutor. Em seu reinado há o inverno eterno, sem Natal, sem cristandade, que afinal ainda nem existia em Nárnia. Para se manter no poder, precisa destruir não somente os homens, mas o próprio Aslan, o Bem maior, simbolicamente Jesus Cristo, o que não acontece.

Em uma perspectiva metafórica, como já dissemos, o inverno simboliza a morte, enquanto a primavera ou mesmo o verão simbolizam fertilidade, sexualidade, renovação, ressurreição e amadurecimento, sendo o conto andersiano, portanto, um rito de passagem, no qual temos representações da morte, das primeiras experiências sexuais ou amorosas, do embate feminino, o duplo solar que enfrenta seu reflexo espelhado, seu lado gélido e sombrio. Como uma semente, morre para renascer. A redenção pelo amor, tão cultuada pelos escritores românticos, assume um nível metafísico, constituindo-se na própria ressurreição de Kay.

Observamos a intenção de Lewis para apagar os índices de sexualidade observados no conto A Rainha da Neve, esses, inclusive, com raízes mitológicas e pagãs. Contudo, ao utilizar personagens que dialogam com o conto e com essa mitologia, acaba por revelar o que queria manter oculto: a sexualidade e os desejos interditos.

Ao finalizarmos este texto, ratificamos a ideia inicial de que a misteriosa rainha de cabelos platinados, construída a partir de imagens linguísticas e uma intrincada rede mitológica, 
adquire sobrevidas e passa a ser refigurada em diferentes contextos e linguagens, permanecendo ainda viva em nossa contemporaneidade.

Em comum, essas sobrevidas possuem beleza e mistério, mas diferem em sua vilania, atitudes maléficas e objetivos obscuros. Entre o divino e o humano, apresentam-se muitas vezes como seres ambivalentes. Ora como seres amaldiçoados, ora como a pura representação do mal; mas femininas em sua essência. 


\section{Referências}

ANDERSEN, Hans Christian. Os contos de Hans Christian Andersen. Edição de Noel Daniel. Direção artística. Andy Disl e Noel Daniel. Londres: Taschen.2017.

. Contos de Andersen. Trad. do dinamarquês por Guttorm Hassen. Ilustrações originais de Vilhem Pedersen e Lorenz Frolich. Rio de Janeiro: Paz e Terra, 1978.

ANDERSEN, Hans Christian. The true story of my life. Translated by Mary Howitt. London, 1847.

BECKER, Udo. Dicionário de Símbolos. Tradução Edwino Royer. São Paulo: Paulus, 1999.

BULFINCH, Thomas. O livro da mitologia. Tradução Luciano Alves Meira. São Paulo: Martin Claret, 2013.

CAMPBELL, Joseph. O herói de mil faces. São Paulo: Cultrix, 2004.

CHEVALIER, J e Gheerbrant, A. Dicionário de Símbolos (mitos, sonhos, costumes, gestos, formas, figuras, cores e números.)12 ed. Rio de Janeiro. José Olympio, 1982.

COELHO, Nelly Novaes Panorama Histórico da literatura infantil e juvenil. São Paulo: Ática, 1991.

Literatura infantil: teoria, análise e didática. São Paulo: Moderna, 2006.

FRANCHINI, A. S.; SEGANFREDO, C. As melhores histórias da mitologia nórdica.7. ed. Porto Alegre: Artes e Ofícios, 2008.

FREUD, Sigmund. "O tema dos três escrinios" (1913). Freud (I9I I-I9I3) Observações psicanalí- 
ticas sobre um caso de paranoia relatado em autobiografia ("O caso Schreber"), artigos sobre técnica e outros textos: Obras completas, Volume 10. Trad. Jayme Salomão. Imago: Rio de Janeiro, 1996.

HILL, Jim. Countdown to Disney "Frozen": How one simple suggestion broke the ice on the "Snow Queen" 's decades-long story problems. The Jim Hill Media Podcast Network 18 Oct 2013 Disponível em http://jimhillmedia.com/ . Acessado em 10 Ago 2018.

LEDERER, Wolfgang. The kiss of The Snow Queen: Hans Christian Andersen and Man's redemption by Woman. University of California: Press, Berkeley / Los Angeles / London 1986.

LEWIS, C. S. As crônicas de Nárnia: O leão, a feiticeira e o guarda-roupa. Trad. Paulo Mendes Campos. 4 ed. São Paulo. Martim Fontes, 2010.

MILLER, Jennifer L. "No Sex in Narnia? How Hans Christian Andersen's "Snow Queen” Problematizes C.S. Lewis's The Chronicles of Narnia,"Mythlore: A Journal of J.R.R. Tolkien, C.S. Lewis, Charles Williams, and Mythopoeic Literature: Vol. 28 : No. 1, Article 8. Available at: https://dc.swosu.edu/mythlore/vol28/iss1/8, . (2009)

REIS, Carlos. "Para uma teoria da figuração. Sobrevidas da personagem ou um conceito em movimento". Letras de Hoje, Porto Alegre, v. 52, n. 2, p. 129-136, abr.-jun. 2017

. Dicionário de estudos narrativos. Lisboa: Almedina, 2018.

SURREL, Jason. Os segredos dos roteiros da Disney. São Paulo: Panda Books, 2009.

WUNENBURGER, Jean-Jacques. O Imaginário. São Paulo: Edições Loyola,2007. 